ppi $201502 Z U 4645$

Esta publicación científica en formato digital es continuidad de la revista impresa ISSN-Versión Impresa 0798-1406 / ISSN-Versión on line 2542-3185Depósito legal pp $197402 Z$ U34

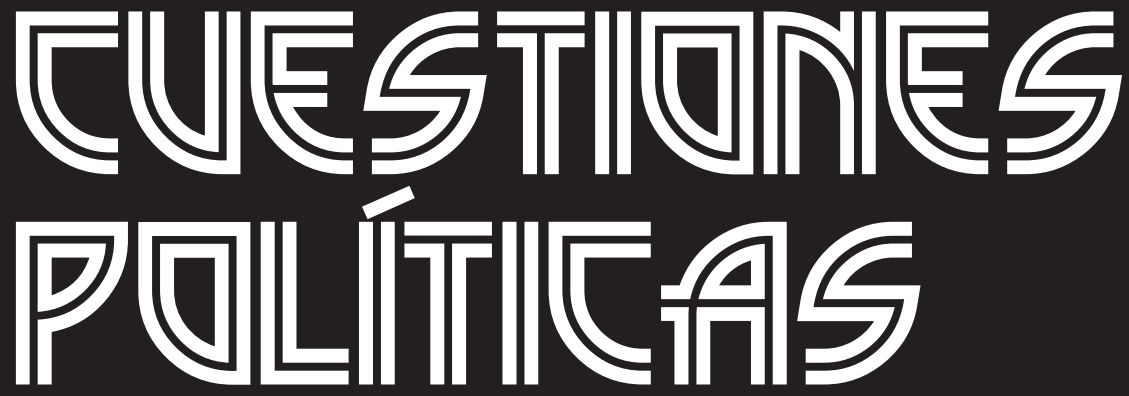

Instituto de Estudios Políticos y Derecho Público "Dr. Humberto J. La Roche" de la Facultad de Ciencias Jurídicas y Políticas de la Universidad del Zulia Maracaibo, Venezuela
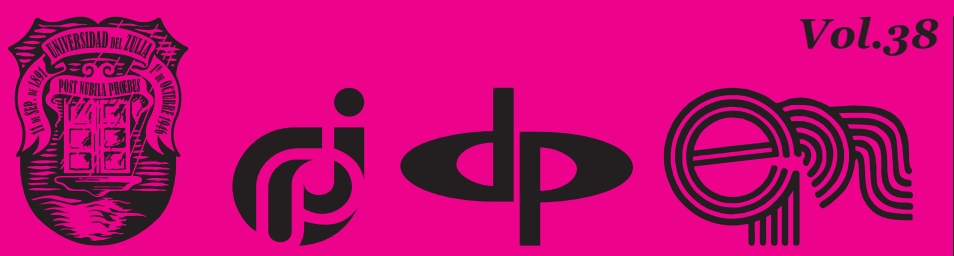

$N^{\circ}$ Especial 1era Parte 2020 


\title{
Computer crimes on the COVID-19 scene: analysis of social, legal, and criminal threats
}

\author{
DOI: https://doi.org/10.46398/cuestpol.38e.31
}

\begin{abstract}
Alexandra Yuryevna Bokovnya * Zarina Ilduzovna Khisamova ** Ildar Rustamovich Begishev *** Elvira Yuryevna Latypova $* * * *$ Elena Vladimirovna Nechaeva $* * * * *$
\end{abstract}

\begin{abstract}
In January 2020, the World Health Organization announced an outbreak of SARS-CoV2, which caused COVID-19 coronavirus disease. Soon, a continuous outbreak of coronavirus infection was declared a pandemic. This situation has led to an increase in cybercrime. Cybercriminals did not stray from the situation and used the pandemic to commit various digital frauds and cyberattacks. As a result, the objective of the investigation was to analyze computer crimes at the COVID-19 scene and identify their social and legal consequences. This is a documentary-based investigation. It is concluded that, security standards have deteriorated in the context of forty social as many organizations were not prepared for remote work and the number of victims of cybercrime will only grow soon. International organizations and law enforcement agencies in many countries issue many recommendations to prevent digital criminal acts against businesses and citizens. This situation also prompted active legislation around the world to deal with the crisis. Most of the rules adopted in recent months are likely to be derogated.
\end{abstract}

* Ph. D. in Law, Faculty of Law, Department of Criminal Law, Kazan Federal University, Kazan, Russia (Russian Federation). ORCID ID: https://orcid.org/oooo-0oo2-6395-0893. Email: kafedra.ksu@ yandex.ru

** Ph. D. in Law, Department of Planning and Coordination of Research Activities, Head, Research Department, Krasnodar University of the Ministry of Internal Affairs of the Russian Federation, Krasnodar, Russia (Russian Federation). ORCID ID: https://orcid.org/oooo-00o3-0561-8718. Email: alise89@inbox.ru

*** Ph. D. in Law, Senior Researcher, Kazan Innovative University named after V.G. Timiryasov, Kazan, Russia (Russian Federation), e-mail: begishev@mail.ru, ORCID ID: https://orcid.org/oooo-ooo15619-4025

**** Ph. D. in Law, Department of Criminal Law and Procedure, Kazan Innovative University named after V.G. Timiryasov, Kazan, Russia (Russian Federation). ORCID ID: https://orcid.org/oooo-0002-73904962. Email: elatypova@ieml.ru

*****Ph. D. in Law, Department of Criminal Law Disciplines, Chuvash State University by I.N. Ulyanov, Cheboksary, Russia (Russian Federation). ORCID ID: https://orcid.org/oooo-0001-8742-1905. Email: nechaeva_ev@mail.ru 
Alexander Yuryevich Epikhin , Oleg Aleksandrovich Zaitsev, Sergei Vladimirovich Tasakov, Elena Vladimirovna Nechaeva y Andrey Viktorovich Mishin

Keywords: COVID-19 pandemic; regulation of social and legal consequences; criminal risks; cybersecurity; cybercrime.

\section{Delitos informáticos en la escena del COVID-19: análisis de las consecuencias sociales, legales y las amenazas criminales}

\section{Resumen}

En enero de 2020, la Organización Mundial de la Salud anunció un brote de SARS-CoV2, que causó la enfermedad por coronavirus COVID-19. Pronto, un brote continuo de infección por coronavirus se declaró pandemia. Esta situación ha provocado un aumento de los delitos informáticos. Los ciberdelincuentes no se alejaron de la situación y utilizaron la pandemia para cometer diversos fraudes digitales y ciberataques. En consecuencia, el objetivo de la investigación fue analizar los delitos informáticos en la escena del COVID-19 e identificar sus consecuencias sociales y legales. Se trata de una investigación de base documental. Se concluye que, los estándares de seguridad se han deteriorado en el contexto de cuarentana social, ya que muchas organizaciones no estaban preparadas para el trabajo remoto y el número de víctimas de delitos cibernéticos solo crecerá en el futuro cercano. Las organizaciones internacionales y los organismos encargados que hacen cumplir la ley de muchos países emiten un gran número de recomendaciones para prevenir la comisión de actos delictivos digitales contra empresas y ciudadanos. Esta situación también provocó una legislación activa en todo el mundo para hacer frente a la crisis. Es probable que la mayoría de las normas adoptadas en los últimos meses se deroguen.

Palabras clave: pandemia de COVID-19; regulación de las consecuencias sociales y legales; riesgos penales; ciberseguridad; ciberdelito.

\section{Introduction}

On April 9, 2020, the International Monetary Fund (IMF) stated that the coronavirus pandemic triggered an economic downturn, which has been last experienced by the world under the Great Depression and could be much worse than the global financial crisis. As countries apply the necessary quarantine measures and social distance methods to contain a pandemic, the world is in a state of great lockdown. The magnitude and 
speed of the following activity are unlike anything experienced in our lives (Kentikelenis et al., 2020).

Consequences of the crisis, having no analogues in recent history, are not yet predictable, and largely depend on the virus epidemiology, the effectiveness of containment measures, as well as on the development of therapeutic agents and vaccines, being difficult to predict.

In addition, many countries face many crises now - the health crisis, the financial crisis, as well as the collapse in commodity prices, which interact in a complex way.

The Great Lockdown also provoked an exponential increase in fears in the society not only for the health of yourself and your relatives but also forebodings of a threat of catastrophic developments. In conjunction with social distancing and massive dissemination of fake news, such a public attitude has become the object of intense interest of the criminal communities and individual cybercriminals. Criminals quickly caught up the opportunity to take advantage of the crisis by adapting their criminal activity methods to the prevailing conditions. Countries around the world report an increase in cybercrime during a pandemic (Saez et al., 2020).

\section{Materials and methods}

The methodological basis of the study is a systematic approach to studying the socio-legal consequences of the great lockdown introduction due to the pandemic. While processing of factual material, the authors used such traditional scientific methods as dialectical, logical, scientific generalizations, content analysis, comparative analysis, synthesis, source study, etc. Based on a comprehensive analysis, we made conclusions regarding the socio-legal consequences and criminal threats of the pandemic in this study.

\section{Results}

One of the key problems of analytical understanding of COVID-19 pandemic consequences is forecasting of the key negative trends in social and economic development. Without doubt, given the uniqueness of such pandemic for world history, it is not possible to compare or evaluate its consequences with the previous global crises. However, given the current trends, it seems possible to assess the effectiveness of certain measures taken by our governments. 
Alexander Yuryevich Epikhin, Oleg Aleksandrovich Zaitsev, Sergei Vladimirovich Tasakov, Elena Vladimirovna Nechaeva y Andrey Viktorovich Mishin

According to the IMF experts, assuming that the pandemic will disappear in the second half of 2020 and that political actions taken around the world will be effective in preventing large-scale bankruptcies of firms, long-term job losses and financial problems throughout the system, it is expected a global growth up to 5.8 percent in 2021. However, the cumulative loss of world GDP for 2020 and 2021 due to the pandemic crisis could be around 9 trillion dollars, which is more than the combined economies of Japan and Germany.

In response to the growing health emergency and rapidly deteriorating economic prospects, national authorities and multilateral organizations around the world are considering the unprecedented policy measures ${ }^{6}$. In response, most countries have temporarily increased the unemployment benefits and expanded their social protection systems to a particular degree, as we mentioned above. Although some of these temporary emergency measures will cease to apply over time, making some of these provisions permanent and improving tax relief systems can also automatically stabilize people's incomes in case of future epidemics and crises. The following should be noted amount the key features of social support measures undertaken by countries.

First, the provision of differentiated (more generous for the poorest) allowances and benefits for vulnerable groups.

For example, approximately 2.3 trillion US dollars (about $11 \%$ of GDP) was allocated to provide one-time tax benefits to individuals; to increase unemployment benefits; to ensure a food safety network for the most vulnerable groups; as well as to prevent corporate bankruptcy by providing loans, guarantees and support to the Federal Reserve under the CARES Act in the USA.

According to the IMF experts, social protection systems can improve redistribution, if a larger share of benefits and allowances account for the poorest 20 percent of the population than the richest 20 percent of the population. Secondly, the preservation of incentives to work and assistance in finding work, obtaining health services, and passing educational and training programs.

On March 15, Austria adopted the General Civil Code, which declared COVID-19 to be a force majeure, allowing the companies forcing their employees to use up to two weeks of vacation accumulated in the previous years. The employers pay only for hours worked, and the rest is paid from the budget. Starting April 2, households can hold up the rent to their homeowners until the end of 2020.

6 For more information it is recommended to consult UN World Economic Situation and Prospects: April 2020 Briefing, No. 136. 1 April 2020. 
In Belgium, the federal government announced a fiscal envelope of 10 billion euros to overcome the crisis (about 2.5\% of GDP, including liquidity measures) and 50 billion euros (more than $11 \%$ of GDP) of guarantees for new bank loans granted to the companies and self-employed. On March 17 , the Italian government adopted "Cura Italia" emergency package in the amount of 25 billion euros (1.4\% of GDP).

In the UK, an independent government forecaster, the Office of Budget Responsibility (OBR), made a warning on April 14 that the country's economy could contract by a record $35 \%$ by June 2020. Support measures of unprecedented scale have also been taken in a country that, along with Italy, is one of the countries most affected by the epidemic.

Thirdly, the aim is to prevent the formation of a disparate, complex network of social protection programs that are more expensive to work with and do not provide people with fair and consistent support. The measures taken by the Government of the Russian Federation to support the economy during a pandemic are generally identical to the measures taken in all countries around the world.

The Government of the Russian Federation approved the Subsidy Provision Rules from the federal budget to Russian credit institutions for the reimbursement of shortfalls in their income on loans issued to SMEs for urgent needs in 2020 to support and maintain employment, as well as the Subsidy Provision Rules from the federal budget to Russian credit institutions in 2020 to ensure deferred loan payments. The total fiscal package is currently estimated at $2.8 \%$ of the country's GDP. These measures, along with measures of social support for the population, are targeted and implemented, bypassing bureaucratic delays that could reduce their effectiveness.

Based on these criteria, governments of advanced economies can improve their social protection systems by expanding the reach of existing programs and improving the impact of subsidies and benefits on people's lives. According to the UN forecasts, quality public investment in health systems is needed to protect people and minimize the risks associated with future epidemics. Other priority areas include infrastructure, green technologies, as well as wind and solar energy, and moving towards other Sustainable Development Goals, such as education and access to clean water and sanitation.

\section{Discussion}

However, in addition to positive forecasts, it is worth focusing on those social problems that acquired a new colour during the pandemic. Most 
Alexander Yuryevich Epikhin, Oleg Aleksandrovich Zaitsev, Sergei Vladimirovich Tasakov, Elena Vladimirovna Nechaeva y Andrey Viktorovich Mishin

experts unanimously note that the trend of this era is inequality. Inequality of the future is not the result of someone's desire, greed, or incorrect policy, but is the result of the development of modern technologies that generate inequality of professions, and, therefore, income inequality.

Quarantine and the Great Lockdown also provoked an exponential increase in fears in the society not only for the health of yourself and your relatives but also forebodings of a threat of catastrophic developments. In conjunction with social distancing and massive dissemination of fake news, such a public attitude has become the object of intense interest of the criminal communities (Begishev et al., 2020) and individual criminals (Khisamova et al., 2020; Latypova et al., 2018). Often, cybercrime involves the use of artificial intelligence technology (Begishev \& Khisamova, 2018; Khisamova \& Begishev, 2019).

There was an expansion in the scope of people's education under the influence of digitalization. It becomes available to almost everyone. But there is also a developing countertrend: elite Socratic education (small groups led by a teacher). Due to the use of online technologies, quality education is becoming more affordable and cheaper, but elite education is becoming more expensive. Education becomes elite, involving direct contact between the student and the professor, the teacher.

Growing restrictions on people's movement and restrictions in Europe and North America have a strong impact on the service sector, especially in those filed that relate to physical interactions, such as retail, leisure, hotel business, and transportation services. Together, they make up more than a quarter of all jobs in these countries. As businesses lose their incomes, the unemployment is likely to skyrocket, transforming the supply-side shock into a broader demand-side shock for the economy. The negative effects of continued restrictions on economic activity in the developed countries will soon spread to developing countries through trade and investment channels. A sharp decline in consumer spendings in the European Union (EU) and the USA will reduce imports of consumer goods from the developing countries. In addition, global manufacturing production may decline significantly amid likely disruptions in the global supply chains.

According to experts, when the Great Lockdown is over, a quick economic recovery is possible only with wide budget support. This includes public investment in health, infrastructure, and climate change. Highdebt countries will need to carefully balance between short-term financial support for the recovery stage and long-term debt sustainability.

The actions of central banks alleviate financial stress, ensure the continuous functioning of financial markets, and provide loans to the enterprises and households affected by the crisis. As soon as social restrictions are removed and the market confidence returns, a long period 
of very low-interest rates can help support the economic recovery.

Supporting recovery through fiscal policy instruments, while managing public debt at its higher levels, is a delicate balancing task. The pandemic and its economic consequences, as well as policy responses, have affected a substantial increase in budget shortages and public debt. With the pandemic retreat and the beginning of economic recovery, it is expected that the public debt will be stabilized, albeit at a new, higher level. If economic recovery requires more time than expected, the dynamics of debt indicators may be more unfavourable.

The current global lockdown has become a catalyst for enhanced lawmaking around the world. There are many norms that are temporary in nature. And a number of experts predict the need for not only the "regulatory guillotine" already announced in the Russian Federation but also the "coronavirus one" in the near future. The massive adoption of the rules that have not passed the due diligence procedure will undoubtedly require a detailed study by the lawyers and their cancellation.

After the pandemic, it will also be necessary to resolve all the changes that were de facto introduced during it:

- Legal regulation of distant services.

- Legal regulation of already changed trust algorithms for the counterparties, new models of verification and interactions in the service market and the electronic commerce rules.

- Protection of the digital profile as a response to a surge of criminal attacks on personal data.

- Regulation of the balance of personal freedom and public safety when applying digital models of tracking and control, creating a digital profile, collecting and analyzing big data, assessing the legal capacity of digital platforms and digital solutions, distance education, as well as electronic court decisions;

- regulation of the risks of data leakage, violation of rights to access the software due to work at home.

A special issue is a legal regulation and responsibility for "fakes", where the line between truth and false is sometimes not always distinguishable. The growing misinformation around COVID-19 continues to spread throughout the world, which could have potentially harmful consequences for the public interest with far-reaching prospects.

Without doubt, the security standards have deteriorated in the context of lockdown, as many organizations were not ready for remote work, and the number of cybercrime victims will only grow in the near future. 
Alexander Yuryevich Epikhin , Oleg Aleksandrovich Zaitsev, Sergei Vladimirovich Tasakov, Elena Vladimirovna Nechaeva y Andrey Viktorovich Mishin

International organizations and law enforcement agencies of many countries issue a large number of recommendations on preventing the commission of digital criminal acts against companies and citizens.

Today it is already possible to clearly distinguish the groups of criminal attacks that, during the lockdown period, acquired the nature of stable trends:

- Massive cyberattacks on the recently (and often quickly) deployed remote access infrastructure or remote working infrastructure.

- The growth of phishing attacks and the spread of malware in connection with the digital audience growth.

- Adaptation of "classic" fraud schemes using social engineering methods.

- Attacks and hacking of digital communication platforms (“Zoombombing”).

- Growth of criminal phenomena in online gaming.

- Increased demand and distribution of pornographic material through social networks, encrypted applications and Darknet.

\section{Conclusion}

There was an expansion in the scope of people's education under the influence of digitalization. It becomes available to almost everyone. At the same time, the education that stipulates direct communication between the student and the teacher has acquired the nature of elitism. In addition to the social issue, the issue of economy restoration to a pre-crisis level is particularly acute on the agenda of governments of all countries around the world. During a pandemic, with the help of large injections of monetary resources, the countries are trying not only to prevent a crisis deepening but also to ensure economic recovery in the shortest possible time. Lockdown provoked active lawmaking around the world. Most of the norms adopted over the past few months are likely to be abolished, so it seems quite possible to conduct a "coronavirus regulatory guillotine" after the pandemic.

\section{Acknowledgement}

The work is performed according to the Russian Government Program of Competitive Growth of Kazan Federal University. 


\section{References Bibliographical}

BEGISHEV, Ildar R; KHISAMOVA, Zarina I. 2018. "Criminological Risks of Using Artificial Intelligence” In: Russian Journal of Criminology. Vol. 12, No. 6, pp. 767-775 (In Russian).

BEGISHEV, Ildar R; KHISAMOVA, Zarina I; NIKITIN, Serge G. 2020. "The Organization of Hacking Community: Criminological and Criminal Law Aspects” In: Russian Journal of Criminology. Vol. 14, No.1, pp. 96-105 (In Russian).

KENTIKELENIS, Alexander; GABOR, Daniela; ORTIZ, Isabel; STUBBS, Thomas; MCKEE, Martin; STUCKLER, David. 2020. "Softening the blow of the pandemic: will the International Monetary Fund and World Bank make things worse?” In: The Lancet Global Health. Vol. 8, No. 6, pp.758-759.

KHISAMOVA, Zarina I; BEGISHEV, Ildar R; LATYPOVA, Elina Yu. 2020. "Digital Crime in the Context of a Pandemic: Main Trends" In: Russian Journal of Criminology. Vol. 14, No, 4, pp. 80-90 (In Russian).

KHISAMOVA, Zarina I; BEGISHEV, Ildar R. 2019. "Criminal Liability and Artificial Intelligence: Theoretical and Applied Aspects" In: Russian Journal of Criminology. Vol. 13; No. 4, pp. 564-574.

LATYPOVA, Ekaterina.Yu; NECHAEVA, Evgeniya V; GILMANOV, Edward Magasumjanovich; ALEKSANDROVA, Nelda. V. 2018. "Infringements on Digital Information: Modern State of the Problem" In Proceedings of the 17th International Scientific Conference «Problems of Enterprise Development: Theory and Practice». 20th - 21st December 2018. Samara, Russia.

LIN, Qi-guang; ZHAO, Song; GAO, Dan; LOU, Yijun; YANG, Shiping; MUSA, Salihu S; WANGB, Mahz; CAIG, Yardt; WANGG, Wei; YANGH, linzj; HE, D. 2020. "A conceptual model for the outbreak of Coronavirus disease 2019 (COVID-19) in Wuhan, China with individual reaction and governmental action" In: International Journal of Infectious Diseases. No. 93, pp. 211-216.

SAEZ, Marc; TOBIAS, Aurelio; VARGA, Diego; BARCELÓ, Maria Antònia. 2020. "Effectiveness of the measures to flatten the epidemic curve of COVID-19. The case of Spain" In: Science of The Total Environment. 138761. Available online. In: https://www.ncbi.nlm.nih.gov/pmc/ articles/PMC7166106/. Consultation date: 10/03/2020. 
Alexander Yuryevich Epikhin , Oleg Aleksandrovich Zaitsev, Sergei Vladimirovich Tasakov, Elena Vladimirovna Nechaeva y Andrey Viktorovich Mishin

UNITED NATIONS. 2020. UN World Economic Situation and Prospects: april 2020 Briefing, No. 136. Available online. In: https://www.un.org/ development/desa/dpad/publication/world-economic-situation-andprospects-april-2020-briefing-no-136/. Consultation date: 26/04/2020.

WATANABE, Yasunori; BERNDSEN, Zachary; RAGHWANI, Jayna; SEABRIGHT, Gemm A; ALLEN, Joel; PYBUS, Oliver; CRISPIN, Max. 2020. "Vulnerabilities in coronavirus glycan shields despite extensive glycosylation" In: Nature communications. Vol. 11, No. 1, pp. 1-10. 


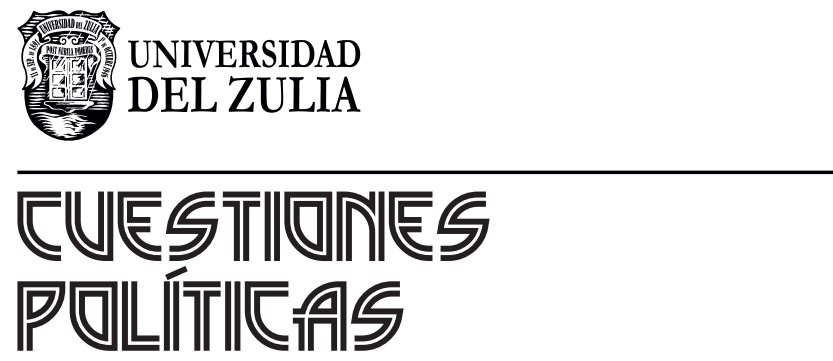

Vol.38 NEspecial

Esta revista fue editada en formato digital y publicada en octubre de 2020, por el Fondo Editorial Serbiluz, Universidad del Zulia. Maracaibo-Venezuela 